\title{
The effect of sorbitol and white sweet potatoes (Ipomea batatas L.) inulin extract application on marshmallow physical, chemical and organoleptic properties
}

\author{
*Yudhistira, B., Putri, A.K. and Prabawa, S. \\ Food Science and Technology, Faculty of Agriculture, Sebelas Maret University, Surakarta
}

\begin{abstract}
Article history:
Received: 29 July 2020

Received in revised form: 27

August 2020

Accepted: 14 October 2020

Available Online: 24 January 2021
\end{abstract}

\section{Keywords:}

Inulin,

Marshmallow,

Sorbitol,

White Sweet Potato

DOI:

https://doi.org/10.26656/fr.2017.5(1).405

\section{Introduction}

Marshmallow refers to a confectionery product which is snack with soft foam texture in various shapes, aromas and colors. Marshmallow, when eaten, melts in the mouth since it is made from sugar or corn syrup, gelatin, and flavoring ingredients mixture that are whipped until fluffy (Nakai and Modler, 1999). Sorbitol belongs to a natural alcohol sugar with the chemical formula $\mathrm{C}_{6} \mathrm{H}_{14} \mathrm{O}_{6}$. Generally, sorbitol is in the form of white odorless non-cariogenic crystalline powder with the molecular weight of $182.17 \mathrm{~g} / \mathrm{mol}$ and $\mathrm{pH}$ of around 7 , and solubility of $2350 \mathrm{~g} / \mathrm{L}$. Its use in the food industry is very broad, including as sweetener, moisturizer, texture forming and softener. Sorbitol can also be used in diets for diabetics since its metabolic pathway is not dependent on insulin (has low energy and cannot be metabolized) (Marques et al., 2016). As a sucrose substitute sweetener, sorbitol has a calorific value of 2.6 $\mathrm{kcal} / \mathrm{g}$ or equivalent to $10.87 \mathrm{~kJ} / \mathrm{g}$. Since it does not have toxic effects, it is safe for human consumption and does not cause dental caries and is very useful as sugar for diabetics and low-calorie diets (BPOM, 2008).
In general, people consume sweets out of liking and not to obtain the functional value of these foods. In marshmallow production, it can be combined with raw materials that will add functional value to the food, for example by using ingredients that naturally contain fiber. One of the food component with high content of dietary fiber and can be utilized in functional food is inulin, which also has the best prebiotic effect compared to other prebiotics (Roberfroid, 2007).

Sweet potato is a potential inulin source that can be utilized. According to Arfiani (2016) who has tested inulin level on several sweet potato varieties, such as white sweet potato, purple sweet potato, and yellow sweet potato, white sweet potato has the highest inulin content of $5.57 \%$ but is still in its yield form so that there are possible components other than inulin. Blanching and foam mat drying on white sweet potato inulin extraction has higher yield up to $22.53 \%$ (Yudhistira et al., 2020), white Sweet Potato inulin extraction with a precipitation ratio of 1:2 for $12 \mathrm{hrs}$ produced the best inulin yield of $7.72 \%$ (Yudhistira, Suswanti and Luwidharto, 2020), while the highest yield of yellow sweet potatoes is $8.80 \%$ 
with a solvent ratio of 1:3 (deposition time $18 \mathrm{hrs}$ ) (Yudhistira, Suswanti and Anindita, 2020). In this research, there are several stages including extraction, isolation, and marshmallows production using sorbitol sweetener and white sweet potato inulin with different concentrations of sorbitol and inulin. The limited research on inulin content in sweet potatoes is the background for choosing this commodity as research material. This study refers to the application of inulin in white sweet potato (Ipomea batatas L.) which is applied in the making of marshmallows as a food product.

Producing marshmallows with sorbitol sweetener with the addition of white sweet potato inulin extract is expected to produce the processed foods that contain natural prebiotics so as to produce food products that have functional value. The goal of this analysis is to establish the effect of the addition of white sweet potatoes (Ipomea batatas L.) inulin extract and sorbitol on the physical, chemical and organoleptic characteristics of marshmallows and to obtain the best recipe for marshmallows by adding white sweet potatoes (Ipomea batatas L.) inulin extract and sorbitol.

\section{Materials and methods}

\subsection{Materials}

Materials used in this study were white sweet potato (Ipomea batatas L.), aquadest (Merck), ethanol 96\% (Merck), sorbitol (Merck), sugar (Gulaku), gelatin (Gelita), cornstarch (Maizenaku), icing sugar (Fiesta), strawberry essence (Capella), water, barley, $\mathrm{Na}$ phosphate buffer $\mathrm{pH} 6$ (Merck), pepsin enzyme 1\% (Merck), $\mathrm{HCl} 1 \mathrm{~N}$ (Merck), $\mathrm{NaOH}$ (Merck), ethanol 95\% (Merck), $\left(\mathrm{CH}_{3}\right)_{2} \mathrm{CO}$ (Merck), beta-amylase enzymes (Merck), pancreatin (Merck), hexane (Merck), filter paper (Whatman No. 4.2), and ethanol 90\% (Merck).

The tools were divided into five types. First, tools for extraction preparation, consisting of analytical scale (Ohaus), 80 mesh sieve (MBT Sieve Shaker type AG515 ) and cabinet dryer (TEW IC 80EN). Second, the tools for extraction, consisting of waterbath (Memmert), analytical scale (Ohaus), beaker glass (Pyrex), filter cloth (Whatman No. 4.2), vacuum rotary evaporator (KNF RC 600 ), and refractometer (ATC). Third, the isolation tools, consisting of analytical scale (Ohaus), centrifuge (Gemmy), Erlenmeyer (Pyrex), glass funnel (Pyrex), beaker glass (Pyrex), filter paper, spatula stirrer (Pyrex), centrifuge tube (Iwaki Pyrex), cabinet dryer (TEW IC $80 \mathrm{EN})$, and tray. Fourth, tools for making marshmallows, consisting of stove (Quantum) and mixer (Phillips). The fifth is tools for analysis, consisting of Universal Testing Machine Zwick/Z0.5 (BL-GRS500N), measuring cup (Pyrex), desiccator (Iwaki Pyrex), oven
(Memmert), analytical scale (AND-GF300), calorimeter (IKA C6000), analytical scale (Mettler AE 160), Erlenmeyer (Pyrex), incubators (Memmert), and shaker (Boeco).

\subsection{Extraction preparation}

The preparation stage for the extraction of fresh white sweet potatoes covered the process of washing, stripping, chopping with a medium size (1-2 mm), drying with a cabinet dryer and flouring (80 mesh sieve) (Kosasih et al., 2015).

\subsection{Extraction}

The results of the extraction preparation were utilized for the extraction process of white sweet potato (white sweet potato flour) then mixed with the flour and aquadest (1: 5), the flour was soaked in aquadest for 1 hour and stirred in a water bath at $80^{\circ} \mathrm{C}$ for 30 mins, then filtered using double layer, and the water was evaporated with a vacuum rotary evaporator at a temperature of $73^{\circ}$ $\mathrm{C}$ for $2.5 \mathrm{hrs}$ (speed $60 \mathrm{rpm}$ ). The extraction process was carried out twice so that all inulin could be extracted (Kosasih et al., 2015).

\subsection{Isolation}

The total sugar was analyzed by taking $2 \mathrm{~mL}$ of the sample which had been diluted beforehand as needed, then added with $0.05 \mathrm{~mL}$ of $80 \%$ phenol solution and vortexed. The solution was then added with $5 \mathrm{~mL}$ of $\mathrm{H}_{2} \mathrm{SO}_{4}$, vortexed and left for 10 mins in the water bath at $25^{\circ} \mathrm{C}$ and calibrated at $490 \mathrm{~nm}$ wavelength (Lorenz, 1959). The analysis of sugar reduction was started by taking $1 \mathrm{~mL}$ of the sample diluted according to the needs into the test tube, plus $0.33 \mathrm{~mL}$ of Rochelle salt $40 \%$ and $1 \mathrm{~mL}$ of DNS reagent, and then heated at $99^{\circ} \mathrm{C}$ for 5 mins to form a brownish-red color then cooled at room temperature and with a spectrophotometer at a wavelength of $575 \mathrm{~nm}$ (Miller, 1959).

\subsection{Precipitation inulin extract}

The white sweet potato extract was adjusted to $30^{\circ}$ Brix, then immersed in $95 \%$ ethanol with a ratio of $1: 2$ for $12 \mathrm{hrs}$, deposited with a centrifuge for 15 mins $(5000$ $\mathrm{rpm}$ ), and dried using an oven at $60^{\circ} \mathrm{C}$ for $6 \mathrm{hrs}$ (Kosasih et al., 2015), is modified by Yudhistira, Suswanti and Luwidharto (2020).

\subsection{Marshmallow production}

Marshmallow was made by 44 grams of gelatin dissolved in water at a temperature of $14-15^{\circ} \mathrm{C}$ and left to stand for 10 mins. Furthermore, the white sweet potato inulin extract $(2 \%$ and $3 \%)$ and sorbitol $(25 \%, 50 \%$, and 
$75 \%)$ were mixed according to the formulation and boiled for 5 mins. All formulations obtained were $\mathrm{F} 1=$ $100 \%$ marshmallow sugar, F2 = marshmallow $100 \%$ sorbitol, F3 = marshmallow $2 \%$ white sweet potato inulin extract: $25 \%$ sorbitol, $\mathrm{F} 4=2 \%$ marshmallow extract white sweet potato inulin: $50 \%$ sorbitol, F5 = marshmallow $2 \%$ white sweet potato inulin extract: $75 \%$ sorbitol, F6 $=$ marshmallow 3\% white sweet potato inulin extract: $25 \%$ sorbitol, $\mathrm{F} 7=$ marshmallow $3 \%$ white sweet potato inulin extract: $50 \%$ sorbitol, F8 = marshmallow 3\% white inulin extract sweet potato: $75 \%$ sorbitol. After that, the inulin and sorbitol extracts were mixed with the gelatin mixture in the basin and then stirred with a mixer at medium speed for 12 mins until foam forms, when the foam had formed, strawberry juice was added. The marshmallow was then poured on a skillet covered with cornstarch that had been mixed with icing sugar. After smoothing it, the top surface of the marshmallow was sprinkled with icing sugar that had been mixed with cornstarch. The next stage of marshmallows is brooded for $24 \mathrm{hrs}$ (Jalasena and Anjani, 2015; Sebayang et al., 2016).

\subsection{Physical, chemical, and organoleptic analysis}

The physical analysis carried out included tensile strength using the Universal Testing Machine Zwick / Z0.5 (BL-GRS500N), density test (Himmelblau, 1996), while chemical analysis included moisture content used thermogavimetry (AOAC, 2005), ash content applied the oven method (AOAC, 2005), total calories used the bomb calorimeter method (Mahajoeno, 2005), dietary fiber used the enzymatic method (AOAC, 1995) and preference tests (Setyaningsih et al., 2010) by applying organoleptic scores as follows: $1=$ very dislike, $2=$ dislike, $3=$ neutral, $4=$ like, $5=$ very like (the largest number indicates the highest level of preference and followed by the next smaller number).

\subsection{Data analysis}

Sensory, physical and chemical analysis was statistically carried out using the one-way ANOVA method. If it shows significant results, it is followed by a significant difference test using Duncan's Multiple Range Test (DMRT) at the significant level $\alpha=0.05$.

\section{Results and discussion}

\subsection{Tensile strength}

As seen in Table 1, marshmallow tensile strength value is in the range of $1.980-4.127 \mathrm{~N}$. The tensile strength value of marshmallow with white sweet potato inulin extract and sorbitol is directly proportional to the addition of white sweet potato inulin extract and sorbitol. The increase in tensile strength values indicates that the texture of marshmallows becomes more viscous and difficult to break during the testing process using Universal Testing Machines (UTM). The high value of tensile strength can indicate that the quality of marshmallows produced is getting better (Yudhistira et al., 2017).

According to Gontard et al. (1992), the factors that influence the tensile strength of a material are the total dissolved solids and the interaction of molecules in them. The difference in the amount, type, and position of sulfate groups also the presence of ions will affect the gel formation process. Kaya et al. (2015) and Desrosier (2008) suggest that gel formation can be influenced by pectin, sugar, acids, and water mixture. The gel formation affects the plastic texture, so this plastic texture makes marshmallows more viscous and not easily broken. Arfiani (2016) states that white sweet potatoes contain fiber including pectin and inulin.

The texture of marshmallows formed is influenced by the mixing process which produces foam in the dough which then becomes marshmallow. Foam in food refers to the continuous dispersion of air bubbles in the liquid to solid or gas phases and is stabilized by active ingredients (Damodaran, 2008). Aerated confectionery products such as marshmallows and nougats are

Table 1. Parameter of marshmallow with white sweet potato (Ipomea batatas L.) inulin extract and sorbitol

\begin{tabular}{ccccccc}
\hline \multirow{2}{*}{ Formula } & \multicolumn{5}{c}{ Parameter } \\
\cline { 2 - 6 } & $\begin{array}{c}\text { Tensile Strength } \\
(\text { Fmax })(\mathrm{N})\end{array}$ & Density $(\mathrm{g} / \mathrm{mL})$ & $\begin{array}{c}\text { Water content } \\
(\% \mathrm{wb})\end{array}$ & $\begin{array}{c}\text { Ash content } \\
(\% \mathrm{wb})\end{array}$ & $\begin{array}{c}\text { Total calories } \\
(\mathrm{cal} / \mathrm{g})\end{array}$ & Dietary fiber $(\%)$ \\
\hline F1 & $2.070 \pm 0.041^{\mathrm{a}}$ & $0.573 \pm 0.007^{\mathrm{a}}$ & $11.820 \pm 0.417^{\mathrm{b}}$ & $0.512 \pm 0.010^{\mathrm{e}}$ & $2534.611 \pm 14.912^{\mathrm{bc}}$ & $1.182 \pm 0.005^{\mathrm{b}}$ \\
F2 & $1.980 \pm 0.144^{\mathrm{a}}$ & $0.579 \pm 0.002^{\mathrm{a}}$ & $19.794 \pm 0.649^{\mathrm{g}}$ & $0.343 \pm 0.019^{\mathrm{b}}$ & $2503.235 \pm 172.885^{\mathrm{c}}$ & $1.800 \pm 0.004^{\mathrm{e}}$ \\
F3 & $2.679 \pm 0.162^{\mathrm{b}}$ & $0.781 \pm 0.059^{\mathrm{d}}$ & $13.141 \pm 0.845^{\mathrm{c}}$ & $0.362 \pm 0,005^{\mathrm{c}}$ & $2144.371 \pm 84.493^{\mathrm{a}}$ & $1.118 \pm 0.012^{\mathrm{a}}$ \\
F4 & $2.879 \pm 0.198^{\mathrm{b}}$ & $0.572 \pm 0.002^{\mathrm{a}}$ & $17.094 \pm 0.393^{\mathrm{a}}$ & $0.422 \pm 0.003^{\mathrm{d}}$ & $2664.948 \pm 26.902^{\text {cd }}$ & $1.184 \pm 0.019^{\mathrm{b}}$ \\
F5 & $4.127 \pm 0.399^{\mathrm{c}}$ & $0.663 \pm 0.023^{\mathrm{bc}}$ & $18.107 \pm 0.417^{\mathrm{e}}$ & $0.269 \pm 0.011^{\mathrm{a}}$ & $2786.102 \pm 72.296^{\text {de }}$ & $2.805 \pm 0.016^{\mathrm{f}}$ \\
F6 & $3.087 \pm 0.174^{\mathrm{b}}$ & $0.839 \pm 0.020^{\mathrm{e}}$ & $10.549 \pm 0.401^{\mathrm{d}}$ & $0.840 \pm 0.007^{\mathrm{h}}$ & $2403.072 \pm 57.228^{\text {de }}$ & $1.811 \pm 0.005^{\mathrm{e}}$ \\
F7 & $3.608 \pm 0.276^{\mathrm{c}}$ & $0.641 \pm 0.041^{\mathrm{b}}$ & $14.600 \pm 0.288^{\mathrm{e}}$ & $0.629 \pm 0.011^{\mathrm{f}}$ & $2582.926 \pm 44.776^{\mathrm{c}}$ & $1.534 \pm 0.004^{\mathrm{d}}$ \\
F8 & $2.804 \pm 0.292^{\mathrm{b}}$ & $0.702 \pm 0.021^{\mathrm{c}}$ & $17.540 \pm 0.757^{\mathrm{ef}}$ & $0.782 \pm 0.009^{\mathrm{g}}$ & $2912.843 \pm 72.323^{\mathrm{e}}$ & $1.455 \pm 0.028^{\mathrm{c}}$ \\
\hline
\end{tabular}

Values are expressed as mean \pm standard deviation. Values with different superscripts in the same column indicate a significant difference at the 0.05 significant level 
produced using high sugar syrup and active agents such as protein, which can be combined with polysaccharides (Lees and Jackson, 1973). Sugar, protein, and polysaccharides can interact with each other and will affect foaming capacity, foam stability and rheological properties. The aeration process will affect changes in texture and rheological properties causing different taste and appearance (Campbell and Mougeot, 1999).

\subsection{Density}

Low marshmallow density values indicate better quality compared to marshmallows with high density, since marshmallows with low density are able to trap more air so it is softer and lighter when consumed and has higher volume (Trilaksani et al., 2009). The amount of volume formed is influenced by the presence of pectin, which serves as gel-forming agent and thickener (Hariyati, 2006).

The density test that has been analyzed statistically using one-way ANOVA and DMRT tests shows that marshmallow density values significantly affected by the addition of white sweet potato inulin extract and sorbitol. The results in Table 1 show that density values in the eight marshmallow formulations range from 0.572 $0.839 \mathrm{~g} / \mathrm{mL}$. According to SNI, marshmallow density values are $0.454 \mathrm{~g} / \mathrm{mL}-0.772 \mathrm{~g} / \mathrm{mL}$ (Trilaksani et al., 2009). The results of this study suggested that the marshmallow density value with the addition of white sweet potato inulin extract and sorbitol was greater than SNI. Furthermore, the density value also tended to decrease with the greater sorbitol concentration and increases with the greater concentration of white sweet potato inulin extract. This was because white sweet potato inulin extract belongs to a type of fiber that contains pectin which is a gelatinizing agent that can affect marshmallow products and different textures on marshmallows (Koswara, 2009).

\subsection{Water content}

Table 1 shows that the addition of white sweet potato inulin extract and sorbitol significantly affected the value of marshmallow water content. Marshmallow water content calculation is in accordance with SNI 3547.2:2008 concerning the standard quality of soft confectionery with the maximum value of $20 \%$ (BSN, 2008). Calculation of the highest marshmallow water content was at F2 (19.794\%) in the $100 \%$ sorbitol formulation and the lowest at F6 (10.549\%) in the formulation of $3 \%$ white sweet potato inulin extract and $25 \%$ sorbitol. The increase in water content is directly proportional to the addition of white sweet potato inulin extract and sorbitol.

Higher water content was caused by sorbitol being hygroscopic and able to bind free water in the product. The higher the addition of sorbitol in food, the more free water is bound (Aini et al., 2016). When sorbitol is added to food products, it has a hydroxyl group that functions to bind free water outside and forms hydrogen bonds with water, while the effect of adding white sweet potato inulin extract is the increase of water content due to the nature of inulin that dissolves in water (Karimi et al., 2015).

\subsection{Ash content}

Table 1 shows the results of the ash content from the 8 marshmallow formulations with white sweet potato inulin extract and sorbitol. The results showed that marshmallow ash content with the addition of white sweet potato inulin extract and sorbitol did not deviate from SNI 3547.2:2008 regarding the standard quality of soft confectionery which is a maximum of $3 \%$ (BSN, 2008). One-way ANOVA and DMRT statistical test results showed the addition of white sweet potato inulin extract and sorbitol on marshmallow significantly affected the ash content. Sartika (2009) states that the lower ash content the better quality of marshmallows produced, based on this theory the best marshmallow formulation is at F5 $(0.329 \%)$. From the results of this study, the marshmallow ash levels were getting higher with increasing white sweet potato inulin extract and sorbitol. This was because the inulin extract derived from white sweet potato and sorbitol contains various minerals. Bradbury and Halloway (1988) state that sweet potato (Ipomoea batatas L.) is one of the agricultural products that contain carbohydrates and high-calorie vitamins (A, C, B1, and $\mathrm{B} 2)$, minerals ( $\mathrm{Fe}, \mathrm{P}$, and $\mathrm{Ca}$ ), protein, fat, and fiber source. Sweet potatoes contain water $(71.1 \%)$, starch $(22.4 \%)$, protein $(1.4 \%)$, fat $(0.2 \%)$, vitamin A (0.01-0.69/100 g), and an adequate mineral source. These minerals will increase the ash content of the product. Ash content associated with minerals of a product and the addition of additional inorganic materials to the product will increase the ash content of the product (Suhardi et al., 2003).

\subsection{Total calories}

Table 1 shows the results of total calorie tests on marshmallows with white sweet potato inulin extract and sorbitol using the bomb calorimeter method. One-way ANOVA and DMRT statistical tests showed that the addition of white sweet potato inulin extract and sorbitol significantly affected the calorie value of marshmallows. The results showed that the greater the percentage of white sweet potato inulin extract and sorbitol added, the greater the caloric content. (BPOM, 2008) states that the calorific value is $2.6 \mathrm{kcal} / \mathrm{g}$ or equivalent to $10.87 \mathrm{~kJ} / \mathrm{g}$. 
According to the previous statement, marshmallow with a greater percentage of sorbitol should have the lower calorie content. However, the addition of sweet potato inulin extract affects the amount of calories in marshmallows due to measurement that often provides incorrect information when distinguishing between carbohydrate types that are available and non-available (Southgate, 1975). Chemically, inulin is a mixture of oligomeric and polymers chain with several fructose molecular variables that join $\beta-2,1$ glycoside bonds and usually includes glucose molecules at the end of the chain (Gao et al.,2016). Thus, based on this theory it can be assumed that white sweet potato inulin extract on marshmallows is read by the test equipment as calories in marshmallows causing calorie content on marshmallows with the addition of white sweet potato inulin extract increases. Therefore, further studies on testing calories in marshmallows by the addition of white sweet potato inulin extract and sorbitol with other methods than bomb calorimeter are needed.

\subsection{Dietary fiber content}

Table 1 shows the results of the analysis of dietary fiber content on marshmallows white sweet potato with inulin extract and sorbitol. The highest dietary fiber content is in F5 (2.805\%) with a formulation of $2 \%$ white sweet potato inulin extract and $75 \%$ sorbitol. The results showed that the addition of a percentage of white sweet potato inulin extract and sorbitol increased dietary fiber content in marshmallows. This is because the fiber content in white sweet potato inulin extract causes the fiber content in marshmallows to be higher. Inulin refers to a natural oligosaccharide produced by many plants. Inulin in plants is stored in roots or tubers (Hidayat, 2006). Inulin is also a natural polymer with fructose monomers. The amount of fructose monomers in a polymer chain varies depending on the source. Inulin is a type of fructose or fructose polymer (fructose monomer combined chain) which mostly contains about 35 fructose units connected to each other in straight chain by $\beta-2,1$ glycoside bond (Gao et al., 2016).

\subsection{Color}

Marshmallows are generally white, but can also be of other colors if additional food coloring is added according to consumer's preference. In this study, no food coloring was added on marshmallows with the addition of white sweet potato inulin extract and sorbitol. Based on the results, all marshmallow formulations had the dominant white color, which means the addition of white sweet potato inulin extract and sorbitol had no effect on the color of the marshmallows produced.

Table 2 shows that panelists assess all marshmallow formulation color parameters at preference level of 3.18 - 3.98 or equivalent to neutral-like. According to panelists, the increase of white sweet potato inulin extract and sorbitol percentage had no effect on the color of marshmallows produced, as shown by only F1 formulation with $100 \%$ sugar which was in a different subset than the other formulations. This was because F1 was a formulation that contained the most sugar, thus the heating process could cause a Maillard reaction between sugar and amino acids contained in the sugar so that it produced a brown color.

\subsection{Aroma}

Other ingredients besides inulin extract of white sweet potato and sorbitol used in marshmallows production in this study consisted of sugar, gelatin, cornstarch, icing sugar, water, and strawberry essence. Out of these ingredients, some that have specific aroma is gelatin, the characteristic aroma of gelatin, icing sugar, the sweet aroma, and strawberry flavor essence, the aroma of strawberry. The aroma of these ingredients will affect the panelists' evaluation of marshmallows with the addition of white sweet potato inulin extract and sorbitol.

Based on one-way ANOVA and DMRT statistical tests, the addition of white sweet potato inulin extract and sorbitol significantly affected the aroma of marshmallow. Table 2 shows the aroma parameter values on marshmallows at the neutral-like level $(3.60-4.22)$.

Table 2. Panelist's preference level of marshmallow with white sweet potato inulin extract and sorbitol

\begin{tabular}{cccccc}
\hline Formulation & Color & Aroma & Taste & Texture & Overall \\
\hline F1 & $3.98 \pm 0.733^{\mathrm{b}}$ & $3.82 \pm 0.616^{\mathrm{abc}}$ & $3.92 \pm 0.859^{\mathrm{b}}$ & $3.78 \pm 0.862^{\mathrm{b}}$ & $3.68 \pm 0.971^{\mathrm{b}}$ \\
F2 & $3.28 \pm 0.987^{\mathrm{a}}$ & $3.70 \pm 0.687^{\mathrm{a}}$ & $3.22 \pm 0.733^{\mathrm{a}}$ & $3.55 \pm 0.986^{\mathrm{b}}$ & $3.20 \pm 0.823^{\mathrm{ab}}$ \\
F3 & $3.25 \pm 0.927^{\mathrm{a}}$ & $4.22 \pm 0.620^{\mathrm{c}}$ & $3.92 \pm 0.859^{\mathrm{b}}$ & $3.00 \pm 0.961^{\mathrm{a}}$ & $2.30 \pm 0.906^{\mathrm{a}}$ \\
F4 & $3.22 \pm 0.981^{\mathrm{a}}$ & $4.12 \pm 0.607^{\mathrm{bc}}$ & $3.95 \pm 0.749^{\mathrm{b}}$ & $3.90 \pm 0.841^{\mathrm{b}}$ & $3.78 \pm 0.733^{\mathrm{b}}$ \\
F5 & $3.28 \pm 0.784^{\mathrm{a}}$ & $3.82 \pm 0.675^{\mathrm{ab}}$ & $3.35 \pm 0.893^{\mathrm{a}}$ & $3.35 \pm 0.921^{\mathrm{ab}}$ & $3.65 \pm 0.662^{\mathrm{b}}$ \\
F6 & $3.28 \pm 0.816^{\mathrm{a}}$ & $3.70 \pm 0.687^{\mathrm{a}}$ & $3.40 \pm 0.709^{\mathrm{a}}$ & $3.32 \pm 0.859^{\mathrm{ab}}$ & $3.35 \pm 0.847^{\mathrm{a}}$ \\
F7 & $3.18 \pm 0.903^{\mathrm{a}}$ & $3.60 \pm 0.709^{\mathrm{a}}$ & $3.18 \pm 0.813^{\mathrm{a}}$ & $3.00 \pm 0.841^{\mathrm{ab}}$ & $3.08 \pm 0.730^{\mathrm{ab}}$ \\
F8 & $3.18 \pm 0.813^{\mathrm{a}}$ & $3.78 \pm 0.733^{\mathrm{a}}$ & $3.30 \pm 0.853^{\mathrm{a}}$ & $3.48 \pm 0.933^{\mathrm{b}}$ & $3.42 \pm 0.675^{\mathrm{bc}}$ \\
\hline
\end{tabular}

Values are expressed as mean \pm standard deviation. Values with different superscripts in the same column indicate a significant difference at the 0.05 significant level 
The formulation whose aroma was most preferred by panelists was F3 (4.22) with $2 \%$ white sweet potato inulin extract and $25 \%$ sorbitol. This shows that panelists dislike marshmallows that use high concentrations of white sweet potato inulin extract and sorbitol because, with the increase in the use of white sweet potato inulin extract and sorbitol, the distinctive aroma of white sweet potato inulin extract and sorbitol also increases.

\subsection{Taste}

Table 2 shows the results of panelists' preference for taste parameters of marshmallow with the addition of white sweet potato inulin extract and sorbitol at values of $3.18-3.95$. The addition of sorbitol has an effect on taste because the more sorbitol is used, the marshmallow will be sweeter. The higher the percentage of sorbitol used, the higher the level of panelists' preference. This shows the success of using sorbitol as a sucrose substitute sweetener, with the advantage of sorbitol having a lower sweetness level compared to sucrose. The sweetness level of sorbitol is 0.5-0.7 times of sucrose with a calorific value of $2.6 \mathrm{kcal} / \mathrm{g}$ or equivalent to 10.87 $\mathrm{kJ} / \mathrm{g}$ (BPOM, 2008).

\subsection{Texture}

In Table 2, the most preferred texture of marshmallow with white sweet potato inulin extract and sorbitol is F4 with $2 \%$ white sweet potato inulin extract and $50 \%$ sorbitol. The higher addition of sorbitol will produce a non-crisp texture that is less preferred by panelists. Sorbitol belongs to a very hygroscopic sweetener that has the ability to bind free water. The higher the addition of sorbitol, the more free water is retained (Aini et al., 2016). Texture parameter is also related to the physical properties of marshmallows, which is tensile strength. As previously explained, marshmallow tensile strength value with the addition of white sweet potato inulin extract and sorbitol tends to increase with the greater concentration of white sweet potato inulin extract and sorbitol used. The high value of tensile strength can indicate the quality of marshmallows produced is getting better. If the tensile strength parameter, the best formulation is with the highest tensile strength, but in organoleptic test texture parameters, panelists tend to prefer marshmallows which break easily or in other words have low tensile strength values.

\subsection{Overall}

The most preferred formulation by the panelists was F4 (3.78), namely marshmallow with white inulin extract formula $2 \%$ sweet potato and $50 \%$ sorbitol. The statistical test results also showed that the addition of white sweet potato extract and sorbitol inulin extract had a significant effect on the overall parameters.
3.12 Best formula determination of marshmallow with white sweet potato (Ipomea batatas L.) inulin extract and sorbitol

The determination of the best treatment is used to determine which treatment is best from a process. Determination of the best treatment is done by using a scoring test with the effectiveness index method. The principle of this test is to give a value in accordance with the contribution of a parameter to the product produced (De Garmo et al., 1984). Each parameter is given a value of $0-1$. The greater effect of a parameter on the expected results, the greater score will be given to these parameters and vice versa.

The parameter that was given the highest value or equal to 1 , is the total calorie and dietary fiber parameters because this study applied sorbitol which has a lower sweetness and calorie level than sucrose. By testing, the total calories in all formulations were compared to the calorific value of marshmallows which applied sucrose sweeteners. Furthermore, the parameters of dietary fiber were also given the highest rating because of the addition of white sweet potato inulin extract to marshmallows in this study. In line with the research by Arfiani ( 2016), white sweet potato contains inulin which is a type of carbohydrate that contains fiber and is classified as a prebiotic. Therefore, testing of dietary fiber in all formulations in this study is needed to determine how much the influence of dietary fiber with the addition of sweet potato inulin extract.

Scoring test results on marshmallows with white sweet potatoes inulin extract and sorbitol can be seen in Table 3, where the best treatment has the highest yield value $(\mathrm{NH})$ among other $\mathrm{NH}$ formulations. In Table 3, the highest NH is in F4 (66.225), so it can be concluded that F4 is the best treatment of all the formulations in this study. Characteristics of marshmallow with F4 formulation of $2 \%$ white sweet potato inulin extract and $50 \%$ sorbitol are tensile strength value of $2.880 \mathrm{~N}$; density of $0.573 \mathrm{~g} / \mathrm{mL}$; water content of $17.094 \%$; ash content of $0.510 \%$; total calories of $2664.949 \mathrm{cal} / \mathrm{g}$; and dietary fiber of $1.184 \%$. Whereas, the sensory test has a color value 3.250; aroma of 4.125; taste of 3.950; texture of 3.600; and overall, of 3.775 .

\section{Conclusion}

The addition of white sweet potato (Ipomea batatas L.) inulin extract and sorbitol significantly affected physical properties (tensile strength and density), chemical (water content, ash content, total calories and dietary fiber), and organoleptic (color, aroma, taste, texture, and overall) of marshmallows. F4 is the best of all formulations in this study. The overall parameter 
Table 3. The best formula marshmallow

\begin{tabular}{|c|c|c|c|c|c|c|c|c|}
\hline \multirow{2}{*}{ Characteristics } & \multicolumn{8}{|c|}{ Formulation } \\
\hline & $\mathrm{F} 1$ & $\mathrm{~F} 2$ & F3 & $\mathrm{F} 4$ & F5 & F6 & F7 & F8 \\
\hline Tensile strength $(\mathrm{N})$ & 2.07 & 1.98 & 2.68 & 2.88 & 4.002 & 3.087 & 3.609 & 3.036 \\
\hline Density (g/mL) & 0.573 & 0.579 & 0.781 & 0.573 & 0.664 & 0.84 & 0.641 & 0.703 \\
\hline Water content (\%wb) & 11.82 & 19.794 & 13.141 & 17.094 & 18.107 & 10.549 & 14.6 & 17.54 \\
\hline Ash content $(\% \mathrm{wb})$ & 0.582 & 0.429 & 0.418 & 0.51 & 0.329 & 0.94 & 0.737 & 0.95 \\
\hline Total calories (kal/g) & 2534.612 & 2603.236 & 2144.372 & 2664.949 & 2786.102 & 2403.073 & 2582.926 & 2912.843 \\
\hline Dietary fiber $(\%)$ & 1.183 & 1.8 & 1.118 & 1.184 & 2.805 & 1.811 & 1.535 & 1.453 \\
\hline \multicolumn{9}{|l|}{ Organoleptic } \\
\hline Color & 3.975 & 3.275 & 3.25 & 3.25 & 3.275 & 3.275 & 3.175 & 3.175 \\
\hline Aroma & 3.925 & 3.7 & 4.225 & 4.125 & 3.825 & 3.7 & 3.6 & 3.775 \\
\hline Taste & 3.925 & 3.225 & 3.925 & 3.95 & 3.35 & 3.4 & 3.175 & 3.3 \\
\hline Texture & 3.775 & 3.55 & 3 & 3.6 & 3.35 & 3.325 & 3.4 & 3.475 \\
\hline Overall & 3.675 & 3.2 & 3 & 3.775 & 3.65 & 3 & 3.075 & 3.425 \\
\hline
\end{tabular}

showed the overall results of all marshmallow formulations with white sweet potato inulin extract and sorbitol according to panelists. The most preferred formulation by panelists was F4 (3.78), marshmallows with $2 \%$ white sweet potato inulin extract and $50 \%$ sorbitol. Statistical test results also showed that the addition of white sweet potato and sorbitol inulin extract significantly affected the overall parameters.

Characteristics of F4 formulation marshmallow with $2 \%$ white sweet potato inulin extract and $50 \%$ sorbitol are tensile strength value of $2.880 \mathrm{~N}$; density of $0.573 \mathrm{~g} /$ $\mathrm{mL}$; water content of $17.094 \%$; ash content of $0.510 \%$; total calories of $2664.949 \mathrm{cal} / \mathrm{g}$; and dietary fiber of $1.184 \%$. Whereas the sensory test has a color value of 3.250 ; aroma of 4.125 ; taste of 3.950 ; texture of 3.600 ; and overall, of 3.775 .

\section{References}

Aini, F.Y., Rachmawanti, D. and Basito. (2016). Kajian Penggunaan Pemanis Sorbitol Sebagai Pengganti Sukrosa Terhadap Karakteristik Fisik dan Kimia Biskuit Berbasis Tepung Jagung (Zea Mays) dan Tepung Kacang Merah (Phaseoulus Vulgaris L.). Jurnal Teknologi Hasil Pertanian, 9(2), 22 - 32. [In Bahasa Indonesia].

AOAC. (1999). Official Methods of Analysis. Official Method 985.29; 993.19; 991.42. Arlington: Association of Analytical Chemists (AOAC) International.

AOAC. (2005). Official Methods of Analysis. Arlington: Association of Analytical Chemists (AOAC) International.

Arfiani, Y.F. (2016). Uji Kadar Inulin pada Beberapa Varietas Ubi Jalar (Ipomea batatas L.) di Kabupaten Ngawi Jawa Timur. Indonesia: Universitas Islam Sunan Kalijaga Yogyakarta, BSc. Thesis. [In Bahasa Indonesia].
BPOM (Badan Pengawasan Obat and Makanan). (2008). Persyaratan Penggunaan Bahan Tambahan Pangan Pemanis Buatan dalam Produk Pangan. Jakarta: Pusat Pengujian Obat and Makanan Baand Pengawasan Obat and Makanan Republik Indonesia. [In Bahasa Indonesia].

Bradbury, J.H. and Halloway, J. (1988). Chemical Composition of Tropical Root Crops. Significance for Nutrition and Agriculture in the Pacific. ACTAR Monograph No. 6. Australia: Ramsay Ware Printing.

BSN (Badan Standarisasi Nasional). (2008). Syarat Mutu Kembang Gula Lunak. SNI 3547.2-2008. Indonesia. [In Bahasa Indonesia].

Campbell, G.M. and Mougeot, E. (1999). Creation and Characterisation Of Aerated Food Products. Trends in Food Science and Technology, 10(9), 283 - 296. https://doi.org/10.1016/S0924-2244(00)00008-X

Damodaran, S. (2008). Amino Acids, Peptides, and Proteins. In Srinivasan, D.O.R., Kirk, P. and Fennema, L. (Eds.). Food Chemistry $4^{\text {th }}$ ed, p. $217-$ 329. Boca Raton: FL. CRC Press.

De Garmo, E.P., Sullivan, W.G. and Canada, J.R. (1984). Engineering Economic. New York: Mc Millan Publishing Company.

Desrosier, N.W. (2008). Teknologi Pengawetan Pangan. UI-Press. Jakarta. [In Bahasa Indonesia].

Gao, J., Brennan, M.A., Mason, S.L. and Brennan, C.S. (2016). Effect of Sugar Replacement With Stevianna and Inulin On The Texture and Predictive Glycaemic Response of Muffins. International Journal of Food Science and Technology, 51(9), 1979 - 1987. https:// doi.org/10.1111/ijfs.13143

Gontard, N., Guilbert, S. and Cuq, J.L. (1992). Edible wheat gluten films: influence of main process variables on film properties using response surface methodology. Journal of Food Science, 57, 190-195. https://doi.org/10.1111/j.1365-2621.1992.tb05453.x 
Hariyati, M.N. (2006). Ekstraksi and Karakterisasi Pektin dari Limbah Proses Pengolahan Jeruk Pontianak. Bogor, Indonesia: Fakultas Teknologi Pertanian. Institut Pertanian Bogor. [In Bahasa Indonesia].

Himmelblau, D.M. (1996). Basic Principles and calculations in chemical engineering. Jakarta: Prenhallindo.

Karimi, R., Azizi M.H, GhasemLouc, M. and Vaziri, M. (2015). Application of Inulin in Cheese as Prebiotic, Fat Replacer and Texturizer: A Review. Carbohydrate Polymers, 119, 85 - 100. https:// doi.org/10.1016/j.carbpol.2014.11.029

Kaya, A.O.W., Suryani, A., Santoso, J. and Rusli, M.S. (2014). Karakteristik and Struktur Mikro Gel Campuran Semirefined Carrageenan and Glukomanan. Jurnal Kimia and Kemasan, 37(1), 19 - 28. [In Bahasa Indonesia]. https:// doi.org/10.24817/jkk.v37i1.1808

Kosasih, W., Sri, P., Diah, R. and Sri, P. (2015). Preparation of Inulin from Dahlia Tubers. Procedia Chemistry, 16, 190 - 194. https://doi.org/10.1016/ j.proche.2015.12.035

Koswara, S. (2009). Teknologi Pembuatan Permen. Retrieved from website: http://tekpan.unimus.ac.id/ wp-content/uploads/2013/07/TEKNOLOGI-

PEMBUATAN-PERMEN.pdf. [In Bahasa Indonesia].

Lees, R. and Jackson, E.B. (Eds.) (1973). Marshmallow and Nougat. In Sugar Confectionery and Chocolate Manufacture, p. 299-323. Boston, Massachusetts: Springer. https://doi.org/10.1007/978-1-4684-1495$0 \_15$

Mahajoeno. (2005). Bomb Calorimeter Method, p. 121 130. Bogor, Jawa Barat, Indonesia: UPT BPP Biomaterial.

Marques, C., Magdouli, S., Rouissi, T., and Brar, K. (2016). Sorbitol Production from Biomass and Its Global Market. In Brar, K., Sarma, S.J. and Pakshirajan, K. (Eds.) Platform Chemical Biorefinery, p. 217 - 227. USA: Elsevier. https:// doi.org/10.1016/B978-0-12-802980-0.00012-2

Nakai, S. and Modler, H.W. (Ed.) (1999). Foods Proteins: Processing Application. London: Wiley VHC.

Roberfroid, M.B. (2007). Prebiotic: The Concept Revisited. The Journal of Nutrition, 137(3), 830S 837S. https://doi.org/10.1093/jn/137.3.830S

Sartika, D. (2009). Pengembangan Produk Marshmallow Dari Gelatin Kulit Ikan Kakap Merah (Lutjanus sp.). Bogor, Indonesia: Institut Pertanian Bogor, Bsc. Thesis.
Setyaningsih, D., Apriyantono, A. and Sari, M.P. (2010). Analisis Sensori untuk Industri Pangan and Agro. Bogor, Indonesia: IPB Press. [In Bahasa Indonesia].

Southgate, D.A.T. (1975). Fiber and other Available Carbohydrate and Energy Effects in the Diet. In White, P.L. and Selvey, N. (Ed.) Proceedings of the Western Hemisphere Nutrition Congress IV. Acton, Massachusetts, USA: Publishing Science Group Inc

Suhardi, Sudarmadji, S. and Haryono, B. (2003). Analisis Bahan Makanan and Pertanian. Yogyakarta, Indonesia: Liberty. [In Bahasa Indonesia].

Trilaksani, W., Nurilmala, M., and Sartika, D. 2009. Formulasi and Karakterisasi Marshmallow dari Gelatin Kulit Kakap Merah (Lutjanus sp.). Prosiding Seminar Nasional Pengolahan Produk And Bioteknologi Kelautan and Perikanan. Indonesia: Kantor Kementerian Pemberdayaan Perempuan. [In Bahasa Indonesia].

Yudhistira, B., Abigail, L.E., Siswanti and Prabawa, S. (2020). The effect of blanching and foam mat drying on the physico-chemical characteristics of white sweet potato (Ipomoea batatas L.) inulin. Food Research, 4(5), 1493 - 1499. https:// doi.org/10.26656/fr.2017.4(5).416

Yudhistira, B., Affandi, D.R. and Nusantari, P.N. (2017). Effect of Green Spinach (Amarantus tricolor L.) and Tomato (Solanum lycopersicum) Addition In Physical, Chemical, and Sensory Properties of Marshmallow as an Alternative Prevention of Iron Deficiency Anemia. IOP Conference Series: Earth and Environmental Science, 102, 012007. https:// doi.org/10.1088/1755-1315/102/1/012007

Yudhistira, B., Siswanti. and Anindita, D., (2020). Pengaruh Rasio Pelarut Dan Waktu Pengendapan Pada Isolasi Inulin Ubi Jalar (Ipomoea batatas). Agrointek, 14 (2), 130-138. [In Bahasa Indonesia]. https://doi.org/10.21107/agrointek.v14i2.6232

Yudhistira, B., Siswanti. and Luwidharto, J.C.N. (2020). The Effect of Solvent Ratio and Precipitation Time on Isolation of Inulin from White Sweet Potato (Ipomoea batatas L.). International Seminar on Agribusiness, 518 (2020), 012009. https:// doi.org/10.1088/1755-1315/518/1/012009 